\title{
Teaching Billing: Metrics of Value in Law Firms and Law Schools
}

\section{Dennis Curtis* \& Judith Resnik**}

In this essay, we explore some of the problems that billing poses for lawyers in practice and in the academy. As our title "teaching billing" suggests, we believe that, although billing is a central practice of lawyers, it receives little sustained attention from either law firms or law schools. Deborah Rhode's important book In the Interests of Justice: Reforming the Legal Profession 1 provides the occasion for these reflections, as she maps some of the conventions of billing, including practices that many would regard as dubious. ${ }^{2}$ The obvious answer is to call for "honest billing," but deciding what constitutes honest billing proves more difficult than one might assume, as does the question of whether incentives can be shaped to facilitate honest billing at either the individual or institutional level.

Below, we map some of the problems embedded in a call for "truth in billing" and explore some of the conceptual and practical issues raised by the equation of time with value. While the literature on billing tends to focus on the institutional problems and the responses at law firms, we argue that the roles played by courts and law schools in shaping norms of acceptable billing also need to be considered. Judges are interesting participants in this debate. A good deal of law addresses the question of fees, as judges sit in judgment of lawyers' bills when asked to award fees either under statutory fee-shifting provisions or when a common fund is created. On one hand, as some judges campaign for higher salaries, they use law firm partner compensation as exemplary of how much money they are missing.3 ${ }^{3}$ Moreover, some judges

* Clinical Professor of Law, Yale Law School. Our thanks to David Pinzón Evans, Vicki Jackson, Cori Van Noy, and Tanina Rostain for thoughtful discussions of these issues.

** Arthur Liman Professor of Law, Yale Law School. Dennis Curtis and Judith Resnik-All rights reserved.

1. Deborah L. RHOde, IN THE INTERESTS OF JUSTICE: ReForming THE LEGAL PROFESSION (2000).

2. Examples include charging more than one client for the same time or tasks and charging clients for time spent in social interactions. Id. at 171-73.

3. See, e.g., William H. Rehnquist, 2001 Year End Report on the Federal Judiciary, THIRD BRANCH, Jan. 1, 2002, at 2 (describing the percentage of lawyers entering the federal judiciary from the public sector and opining that low judicial salaries do not attract lawyers from the private sector). 
resign-attracted by the fees available in the private practice of law or of judging. 4 Yet judges are also public servants who in fact work at salaries less than many of their contemporaries and whose own life choices reflect valuation in terms other than dollars.

When judges rule on lawyers' fees, they express concerns akin to those of regular clients, upset about the large numbers of hours spent and the many lawyers claiming compensation for time on a particular project. Sometimes, judges respond by scouring records to eliminate duplication and, in other instances, by developing means to escape the tedium of oversight by awarding fees independent of the hours spent. Yet hourly bills remain central in the law of fees, in part because of doctrine requiring judges to use that method of value (known as the lodestar) when statutes oblige losing parties to pay their victorious opponents. 5 Therefore, lawyers who rely on statutory fee provisions garner more judicial attention than lawyers able to gain court-awarded fees in antitrust, consumer, or tort aggregates. Yet even in cases in which fees are awarded under the "percentage of the fund" approach, many courts describe themselves as using a "hybrid" method, which compares the dollars netted by the percentage method with how much money would have been paid through a lodestar calculation. 6 Similarly, even those law firms that rely on lock-step compensation systems (rather than linking salaries and bonuses to hours) also obtain and evaluate hourly billing records.

We appreciate efforts to invent alternative forms of billing, both in and out of court.7 But we conclude that, given how much fee law and law firm

4. See, e.g., Reynolds Holding, Judges Find More Reasons to Leave Bench, S.F. CHRON., May 28, 2000, at 3.

5. Hundreds of federal statutes provide for fee shifting from losing to prevailing party. In some instances, one-way fee shifts are provided, such that prevailing plaintiffs may be compensated but, absent frivolous filings, prevailing defendants are not. See, e.g., Christianburg Garment Co. v. EEOC, 434 U.S. 412 (1978); see generally AlBE CONTE, ATTORNEY FEE AWARDS ( 2 d ed. 1993). Under current law, judges must calculate statutory fee shifts by using the hourly method. Moreover, "multipliers" for risk (percentages added to the hourly rate to recognize the contingency in such representation) are no longer permitted. See Burlington v. Dague, 505 U.S. 557 (1992). Recently, the Supreme Court has also imposed limitations on the concept of when a plaintiff has "prevailed" so as to be eligible for a fee award. A lawsuit that is a "catalyst" for a change is no longer grounds for recoupment. See Buckhannon Bd. \& Care Home, Inc. v. W. Va. Dep't of Health \& Human Res., 532 U.S. 598 (2001).

6. See, e.g., In re Cendant Corp. PRIDES Litig., 243 F.3d 722, 735 (3d Cir. 2001) (noting that a lodestar cross-check is the "suggested practice for district courts setting fee awards by the percentage of the fund method").

7. See, e.g., Third Circuit TASK ForCe Report ON THE SElection of Class Counsel (Jan. 2002), available at http://www.ca3.uscourts.gov (describing efforts to find new ways to award attorneys fees through "auctioning" cases to lawyers); Richard C. Reed, Win-Win Billing Strategies: Alternatives That Satisfy Your Clients and You, in A.B.A. SEC. LAW PRAC. MGMT. (1992) (discussing efforts to negotiate alternative billing provisions); NORTH Carolina Bar Association alternattve BIlling Commission, Final Report (1992) (same). 
practices remain rooted in calculations of time, hourly billing will retain a significant place in lawyers' lives. Therefore, we consider pressures at the individual or institutional levels for change within the rubric of the hourly bill.

Law schools have a good deal at stake in the present system, which creates a market for their students and which helps those students pay law school debt. Because law schools help to generate conditions that support unreflective efforts to bill aggressively, we argue that law schools ought to join in the conversation about the role of hourly billing in shaping concepts of professionalization. In some respects, the terms of such a conversation would be familiar, as law schools are much engaged in discursive reflection about commodification, property rights, and liability rules. But, as we explain below, lurking behind the question of hourly billing is the question of hourly law school course credits-for law schools, like law firms, rely on hours as a measure of value. Teaching billing will therefore require legal institutions, be they educational, adjudicative, or service providing, to take on the challenges of exploring the normative implications and pragmatic effects of the practice of measuring the value of lawyers and their education by the number of minutes that they devote to their tasks.

\section{THE BILLABLE HOUR}

Despite a good deal of investigation of and writing about alternative methods of billing, most large law firms today bill their clients on the basis of hours worked by lawyers and paralegals, multiplied by their standard billing rates. 8 Further, as noted, when courts award fees under statutory fee-shifting provisions or as sanctions for misbehavior, they too often turn to the lodestar method-hours times rate. 9 How are such hours calculated? Law firms usually require partners, associates, and paralegals to log their time using fractions of hours that vary from one quarter to one-sixth to one-tenth.

8. As many have chronicled, the reliance on the billable hour is relatively recent, developing in the middle of the twentieth century. See, e.g., George B. Shepherd \& Morgan Cloud, Time and Money: Discovery Leads to Hourly Billing, 1999 U. ILL. L. REV. 91 (arguing that revisions of procedural rules, and specifically the introduction of discovery by the 1938 Federal Rules of Civil Procedure, created the conditions for the emergence of hourly billing). Given the current predominance of hourly billing, the American Bar Association (ABA) has created a Commission on Billable Hours to investigate the kinds of methods used and to develop recommendations for best practices in both hourly and alternative billing systems. Dennis Curtis serves as a member of that Commission but writes here in his individual capacity.

9. See generally Judith Resnik, Dennis E. Curtis \& Deborah R. Hensler, Individuals within the Aggregate: Relationships, Representation, and Fees, 71 N.Y.U. L. REV. 296, 33945 (1996) (discussing the modes of making fee awards and contrasting the lodestar with the "percentage of the fund" approach, often used when courts redistribute the lawyers' fees across a group of co-venturing plaintiffs, and with "auctions," in which judges ask lawyers to submit competitive bids). 
Billable hours do not serve only as a means by which law firms charge their clients. Firms use the number of hours billed as a measure of the utility of the worker and of the success of the firm itself. Hours are a factor in deciding salary levels, raises, bonuses, and promotions. Firms may also use hourly records to equalize work among associates, to calculate "utilization" of associates (how associates are measuring up to the firm's hourly requirements), and to calculate a "realization" figure (how much the firm has actually collected for an associate's work).

One of the intriguing aspects of hourly billing is its lack of stability over time. The number of days in the week and of hours in a day has not changed, but the number of hours that lawyers are expected to work has. Over the past several decades, the hours billed by both associates and partners has gone up substantially.10 For example, Rhode notes that, "when time-based billing began, the expectation was that lawyers would charge between twelve and fifteen hundred hours per year.... [In contrast], current [billable hours] rates range between eighteen hundred and two thousand, and the averages are considerably higher in large firms." 11

Honest counting of billable hours requires substantial time at the office, because not every minute is chargeable to clients. Eating, firm administration, schmoozing, and non-business phone calls and emails all take up workday hours. Thus, Rhode estimates that "[t]o generate two thousand billable hours, attorneys typically need to work ten hours a day, six days a week."12

Time pressures, increases in hours spent, and rising salaries have also altered the working experience and the interactions among lawyers and their clients. ${ }^{13}$ Law firms (especially if large) are increasingly reported by associates to be unpleasant places to work. ${ }^{14}$ Complaints include deterioration of relationships between associates and partners and among associates. Further, attorney-client relationships have changed. Clients, who thirty years ago were considered quite docile (paying thousands of dollars for bills lacking any detail other than as compensation "for services provided"), have shifted to demanding detailed accountings as a predicate to payment. Sophisticated clients now

10. William G. Ross, The Honest Hour: The Ethics of Time-Based Billing by LAWYERS 2-4 (1996).

11. Pp. 170-71.

12. P. 171.

13. P. 9.

14. See, e.g., Ross Guberman, Running From the Law, ThE WASHINGTONIAN, Oct. 2001, at 54 (describing his own experiences as an associate and his delight at having left the practice). In a recent survey of Yale Law School graduates in their fifth year, twenty-four percent of those working as associates reported being "very satisfied" with law practice, as contrasted with sixty-seven percent of those in academics, fifty-eight percent in public services, and fifty-seven percent in business. See Kelly Voight, Learning From Our Graduates, REPORT OF THE YALE 5TH YEAR CAREER DEVELOPMENT SURVEY 1 (2002) (on file with authors). 
scrutinize legal bills to ferret out exorbitant charges and to prevent "padding" through charges for unnecessary work or exaggerated hourly totals. 15

Another effect of the dominance of hourly billing in the private market for lawyers is that it brings with it a tension about how to constitute success in a competitive commercial context. Take a mid-career successful lawyer, billing by the hour. Rates can increase, but at some point ( $\$ 500$ ? $\$ 700$ ? $\$ 1000$ ?), the amount charged per hour tops off. Further, as that lawyer looks about to compare income with other lawyers, that lawyer may not have won the income sweepstakes. Despite high hourly rates and high numbers of hours clocked, firm salaries may be smaller than those of a discrete yet highly visible segment of the legal profession-the contingent fee lawyer representing tort victims in class actions or other forms of aggregate cases. The incomes of a few personal injury lawyers (whose niche in the profession was once equated with the lower end of success if measured by dollars as well as other markers of prestige) ${ }^{16}$ have outstripped the most prestigious partner in the most established firm. The incomes of certain powerful clients-investment bankers, for example-has also risen. Hence, the way that law firms that depend on billable hours keep pace is to develop structured systems in which partners can make significantly high amounts through reliance on a growing number of associates billing a growing number of hours at as great a rate as the market will bear.

\section{BILLING FOR WHAT?}

Locating the rising expectations about the number of hours that ought to be billed in the context of shifts in the legal profession (which in turn are affected by a myriad of other factors, ranging from rules on lawyer advertising to courtbased rules enabling group-based processing) helps to reveal that the seeming simplicity of an hourly billing system hides a series of questions-about which hours to bill, about the uses of billable hours, and about law firm structure and incentives. What is "work" that ought to be billed? Who judges how much of that work is necessary?

Start first with deciding what counts as "work" for which time can be billed. Easy agreement emerges around the idea that lawyers can properly charge for legal work-research; writing memoranda for the purpose of giving advice; representing clients at negotiations, in court, and in administrative proceedings; lobbying or working on legislation and regulations; and perhaps in coordinating public relations or developing information from other professions about projects related to a client's interests. In terms of the quantity of such work, agreement between client and lawyer may in fact be more difficult to

15. Ross, supra note 10 , at 59 (describing one major corporation's policy that attorneys intending to bill "more than ten hours a day" need to obtain advance approval).

16. JOHN P. HeINZ \& EDWARd O. LAUMANN, ChICAGo LaWYers: THE SOCIAL STRUCTURE OF THE BAR 58 (1994). 
achieve, as clients may worry about lawyers who do more than is needed for a particular project. 17

Assume for the moment that a packet of activity constitutes "the work" properly done by lawyers, as contrasted with para-professionals or nonprofessionals. How much of it needs to be done? What work is actually necessary? And who decides? Entailed are questions of delegation-about which workers ought to undertake which tasks and about which workers determine the contours of the task. Most of those who have explored these issues agree that the problem of measuring the quantity of such work that ought to be undertaken is significant. A widely shared perception is that the billable hour affects the lawyer's answer to that question. As William Ross explains,

[o]ne of the most egregious forms of overbilling in many law firms is the almost infinite amount of time that is expended upon research into even the most minute legal issues. As with other forms of overbilling, excessive research probably arises most often out of a genuine belief that the work serves the client's best interests, even if that belief is part of a subconscious rationalization of the desire to inflate the client's bill. 18

But at least from our perspective in the academy, where we observe student work that is not billed by the hour, assessing the amount of work required is not only a problem driven by the lure of making money from hours. We see widely divergent norms of what constitutes sufficient research for law school papers and for briefs written by students representing clients under faculty supervision. The judgments about the necessity of such work are shaped, at least in part, by goals of impressing one's seniors (be they academics and/or lawyers) and of distinguishing oneself from one's peers. Transplant those aspirations into the law firm setting and the desire for approval and the anxiety about peer competition sharpens. Lawyers, especially new lawyers, have been trained to be thorough, creative, and competitive, and much of their self-image and sense of professionalism incorporates these qualities. These cultural forces play an important role in affecting answers-aimed at being "honest"- to the question: what work is necessary? In short, the assessment about whether certain forms of work are "necessary" is subjective, resting on perceptions about the complexity of a given issue in either law or fact, on the training one has had about expectations, and on a person's psychological predispositions and confidence.

17. See generally Ross, supra note 10, at 113-24 (describing clients who complain about lawyers over-researching projects). As another commentator explained:

Simply put, clients want 'good enough' legal services, and outside lawyers frequently strive to deliver work worthy of an At on a law school exam. What are 'good enough' legal services in the client's mind? Corporate counsel want just what is required to obtain the desired business objective. They don't want a grand opus when a short essay will do.... The incremental value of the difference between good enough and perfect legal work is simply not worth the cost to clients.

Debra H. Snider, Enough is Enough, Law.com, at http://www.law.com (Oct. 17, 2001).

18. Ross, supra note 10 , at 113. 
Moreover, forming that judgment is also contingent on two other factors: one's prior experience in having faced comparable issues and other demands upon one's time. Thus, a ready response to the problem of the subjectivity of determining the necessity of a particular form of work for a client is to turn that judgment over to a person better situated to make it: a partner or the in-house counsel of a client.19 Here, of course, is where law firm reliance on large numbers of billable hours undercuts the interest in developing methods to teach young lawyers about how better to assess the amount of time to invest in a given task. Not only does the law firm have an incentive to have many hours billed, the law firm also uses the number of hours billed as a metric for assessing the quality of a particular individual.20 If a firm were to create an effective structure of control over the use of individual (and especially young) lawyers' time, how could the firm then use the amount of time spent by associates to evaluate the abilities of those lawyers? Further, if such structures reduced the number of hours logged, the firm's revenues would fall.

Move from the question of determining the packet of work to another question of billing: can clients be fairly charged for time spent at the behest of the client but not necessarily doing legal work for that client? Travel time is a prime example, as it requires being away from home and office. Travel time represents lost opportunity costs by taking a lawyer away from being able to bill other clients. Law firms and judges, awarding compensation, have offered divergent answers to questions such as whether travel ought to be charged on an hour for hour basis or whether at a lesser rate, and whether time used in transit for other clients ought to be subtracted. For example, Judge Richard Posner concluded that, when "a lawyer travels for a client, he incurs an opportunity cost that is equal to the fee he would have charged that or another client if he had not been traveling."21 Other judges have refused to assume that all of the time spent traveling would have been spent in remunerative time at the office.22 When client and lawyer negotiate, in contrast, it is possible to leave the answers to the market, with lawyers and clients bargaining to reach agreement. Yet the issue of culture remains. Whether answered by courts, by attorney-client bargains, or by law firms' own practices, the responses shape expectations of how much time a "good" lawyer ought to be able to bill.

Another example of differing responses to the question of "what time is billable" comes in the context of time spent with clients in social situations,

19. For example, some clients have instructed their lawyers that research in excess of three hours requires specific approval. See Ross, supra note 10, at 120 (citing Wells Fargo Bank Engagement and Billing Policy for Outside Law Firms (Aug. 30, 1994)).

20. Even when firms have "lock step" compensation systems, under which raises are given yearly to members of a particular "class" without regard to the number of hours worked or clients obtained (for partners), hours are still kept and discussed. Interviews with management at law firms (Oct. 1, 2001).

21. Henry v. Webermeier, 738 F.2d 188, 194 (7th Cir. 1984).

22. See, e.g., FDIC v. Singh, 148 F.R.D. 6 (D. Me. 1993); Fleet Bank of Maine v. Trivers, 799 F. Supp. 1248 (D. Me. 1992). 
where business may be discussed briefly, if at all. These occasions may occur when the lawyer is traveling, perhaps visiting the client in relationship to work for that client. Again, the lawyer is precluded from using that time for alternative opportunities, but is not actually doing legal work for the client. As Deborah Rhode details, "almost ninety percent of partners report that they bill for 'social conversations' with clients, although over ninety percent of corporate executives say they don't expect to be billed for such time."'23 Law firms could justify charging these hours using Judge Posner's approach, while clients, observing and participating in the social interaction, might question whether the hours are justified at the lawyer's normal billing rate.

Yet other problems come that might neutrally be called "multi-tasking" or, more negatively, "double billing." One oft-cited example is a lawyer who bills one client for travel while charging another for work done while traveling. A more complicated example is whether a client ought to be charged more than hours actually spent on a particular piece of research because the lawyer was able to recycle work on an issue already done for another client. The ABA has condemned both practices, stating that "a lawyer who flies for six hours for one client, while working five hours on behalf of another, has not earned eleven billable hours," and "[a] lawyer who is able to reuse old work product has not re-earned the hours previously billed and compensated. when the work product was first generated." 24

But lawyers might respond that, as to the travel problem, each client would have paid the full price for the time spent, and that the lawyer should not be penalized for working for the second client rather than watching a movie or sleeping. As to the recycled work issue, one might argue that the lawyer is hired precisely because of that expertise and the hourly rate charged by the lawyer-or the ability to attract the client at all-suffice as compensation. Conversely, lawyers could argue that, if the research is very specific to a particular kind of issue, such work should be compensated at more than the normal hourly rate because the subsequent clients would be receiving a windfall unless a premium is charged. (Alternatively, one might think about whether to split the same hourly rate across clients, which would require a firm to bill a second client half the cost and return money to the first-a form of self-monitoring that has yet to make it into the literature on billing practices.)

Questions also relate to what could be called "phantom time." Most firms do not have measures of actual time spent but bill in units of time, with rounding off (possibly rounding down but most often rounding up). In most large firms, the minimum unit ranges between six minutes (a tenth of an hour) to fifteen minutes (a quarter of an hour). If all tasks are charged, a one or two

23. P. 171 (citing Talk Ain't Cheap, NAT'L L.J., Nov. 16, 1992, at A2).

24. ABA Comm. on Ethics and Prof'l Responsibility, Formal Op. 379 (1993), reprinted in ABA/BNA LAWYERS, MANUAL ON PROFESSIONAL CONDUCT: ETHCS OPINIONS 1001: 209, 213. 
minute phone call, even if only to leave a message, could be billed as a quarter hour. An email sent or read similarly can produce bills of a tenth or a quarter of an hour. At the end of the day, a lawyer may have accumulated a wealth of hours and a list of charges, well in excess of the actual hours the lawyer spent in the office.

\section{FROM the VANTAGe PoINT OF THE ASSOCIATE: INDIVIDUAL PRACTICES OF BIILING}

Having outlined the kinds of questions embedded in the billable hour, we turn now to glimpse more of the culture of billing. In addition to the published literature, a research seminar taught several times by Dennis Curtis has produced a series of snapshots on the experiences of associates in large law firms. One qualitative report stems from lengthy interviews about billing practices with twenty-five recent law school graduates, all of whom worked in large firms. ${ }^{25}$ The questions fall into two sorts: seeking information directly from the interviewee about his or her own practices and asking about that interviewee's perceptions of others' behavior.

The preliminary results are not surprising to anyone who has followed, however cursorily, scholarly and popular writings about law firm billing practices. All of these associates reported keeping hourly billing records, and all said they knew very well the firm's minimum hourly requirements for retention, promotion, and bonuses. About a third stated that minimum hourly requirements and bonuses played a significant role in their billing practices. Yet most also reported little training on billing and described a variety of methods of accounting that would likely yield as high a total of hours as possible.

Specifically, only four participants reported receiving any formal training or guidance about firm billing policies. ${ }^{26}$ Most of the participants said that they had learned about billing practices informally, from other associates, and by using their own intuition. All reported that billing was an inexact science, in which most kept loose track of their own hours. Some said that their hours were determined at the end of the day, using a rough estimate. Only one of the twenty-five participants recorded her hours in a logbook immediately after completing work for a given client. Almost half of those interviewed discussed inflating (either intentionally or accidentally) their hours. Some reported adjusting hours upward based on how hard they worked for a client. For example, a few reported inflating hours for clients in situations when they fortuitously found information more quickly than normal, thereby charging the client the amount of time the work "should" have taken. Other examples of

25. See Jason Silvers, Billing by Associates (2001) (unpublished manuscript, on file with authors). Silvers conducted twenty-five structured interviews with associates who were in law practice from one to five years.

26. Id. at 3 (discussing three respondents who stated that they had received formal training and a fourth who remembered "some" training). 
questionable billing practices included billing for time thinking about a client's problems while driving to work or taking a shower, billing time discussing a case while at lunch with friends, and billing time clearing up office space and arranging files. As to their thoughts on others, every interviewee thought it probable that most of their colleagues did not bill appropriately all the time. The participants were also unanimous that very few, if any, lawyers would admit to unethical billing practices on a nonconfidential basis. Many of the participants suggested that the majority of associates would not even admit to such practices on an anonymous questionnaire.

Shift from these specifics to the larger picture and realize that, for new associates, hours all too often can become ends in themselves, rather than a means to report how much a client should be charged. The focus for associates, both external (by the firm) and internal (their own sense of how well they are doing) can be seen to be measured not in quality but in quantity of work.

This emphasis on hours comes even before students graduate from law school. Third-year students know not only the areas of law in which a firm specializes, they also know from friends, published sources, and the Internet how many hours the firm demands as a minimum, whether the firm gives hourly credit for pro bono work, and whether the firm requires additional hours above the minimum for "firm development."

Thus, a tendency to privilege the time required to do the work over the value of the work itself begins early, and often is reinforced once the student becomes an associate. Minimum hourly requirements, plus competitiveness, peer pressure, and firm ethos, provide incentives not to fall behind, to do whatever is necessary to bill the required norm, and perhaps to "pad" hours in the process. As one recent "refugee" from law firm practices has explained, "Cheating, known as 'timesheet padding,' is a dirty little secret." He quotes an associate on the verge of leaving a D.C. firm: "What do you expect? There's every incentive for you to lie. The firm rewards you for your hard work and gets more money out of your inflated timesheets, you beat out your colleagues in the rat race, you're shielded from further assignments, there's almost no chance that you'll get caught, and you tell yourself that it's a victimless crime-something you'd never do if your clients weren't wealthy corporations." 27 That sentiment is repeated many times in the literature, including when those injured by the practices are not clients with endlessly deep pockets. Recall the statement of one noted lawyer, charged with fraud, who, while admitting that he padded his hours, argued "so does every lawyer in the country."28

27. Guberman, supra note 14, at 53.

28. P. 171 (citing Susan Koniak, When Did Lawyers' Overbilling Become a Habit?, N.Y. TIMES, May 2, 1998, at A15). 


\section{INSTITUTIONAL PRACTICES}

The young lawyers queried were not gleeful in their accounting of their working lives in the shadow of the billable hour. Although some aspire to high incomes (as the website "greedyassociates.com" 29 suggests), many work in the shadow of heavy debt loads, generated by education at both undergraduate and professional schools. 30 Further, they enter law practice with the aim of being ethical lawyers and without having been asked to reflect on a dominant feature of their professional lives-seeking compensation for their time. ${ }^{31}$

At present, neither law schools nor law firms have focused much on their roles in shaping legal culture. In contrast, courts have done more, in part by being the site of litigation about fee disputes and by proposing to take on a more actively regulatory role.32 Having discussed the challenges for individual lawyers, determining how long to research a given project, when to call time "work" time, and whether to bill simultaneously or differently because of the nature of a task, we turn to consider the place of institutions both in producing the sense of malaise about the propriety of the enterprise of billing and in responding to the problems. Those within one institution-law firms-are well aware that hours are increasingly a problem, rather than a solution. Law schools, on the other hand, have yet to consider not only how they benefit from the wealth enabled by hourly billing, but also how hours organize their own systems of value.

Law firms are the place to start, and a predicate question is whether law firms have any incentives to shift their practices. Above, we noted that many lawyers report working more than two thousand hours a year, and that to do so requires calculating one's hours in ways that always favor claiming the maximum time spent. Because of the inflexible bottom line-twenty-four hours in the day-firms that rely on high annual billings have to understand that some form of generous accounting, at a minimum, is the basis of their

29. This website has received a good deal of publicity in news coverage of law firms' salaries and bonus packages. See, e.g., Laura Mansnerus, As Law Firms Scramble for New Talent, the New Talent Reaps Rewards, N.Y. TIMES, Jan. 30, 2001, at G4. The title of the website deserves consideration as well, for it both provokes and flaunts the desire for money yet also uses the unattractive adjective "greedy," suggesting a potential ambivalence.

30. See Dennis Curtis, Can Law School and Law Firms Be Friends?, 74 S. CaL. L. REv. 65 (2000) (discussing the role law schools play in shaping students' subsequent careers); Lewis A. Kornhauser \& Richard L. Revesz, Legal Education and Entry into the Legal Profession: The Role of Race, Gender, and Educational Debt, 70 N.Y.U. L. REV. 829 (1995) (discussing factors shaping career choices).

31. See Sharon Dolovich, Young Lawyers, Self-Deception, and the Possibility of Integrity, 70 FORDHAM L. REV. (forthcoming 2002) (analyzing the effects of billing pressures on individual understandings of ethical norms).

32. See Advisory Committee on Civil Rules, Judicial Conference of the U.S. Courts, Proposed Amendments to Fed. R. Civ. P. 23, http://www.uscourts.gov/rules/newrules $1 / \mathrm{html}$ (providing a suggested new rule in which judges would select counsel and award fees in class actions certified under that rule). 
billing. Lawyers and firm management can easily drift into an unspoken contract in which lawyers endeavor to find ways to charge as much time as is possible and firms provide minimum training in billing practices and avert their eyes from all but obvious billing excesses.

Minimum hour requirements are particularly likely to encourage this dynamic. In addition to interviews from associates, in the past few years we have interviewed managing and hiring partners of large law firms about hiring, paying, and retaining junior associates. ${ }^{33}$ Billing by associates is a frequent topic. Currently, many firms provide minimal supervision when asking members and associates to make judgments about what hours are required to be spent and how many hours were in fact spent. A great deal of the responsibility for deciding what work is necessary for a client's benefit is placed on the young associates. In a perfect world, there would be enough necessary work to go around, so that everyone could bill the required hours honestly. In the real world, not all associates are perceived as equally competent but each associate has the burden of finding ways to $\log$ the required hours. Associates who are not tapped for work by partners often receive signals (such as being told to "make sure that you let us know when you are available for work," or "make sure that you have done everything the client needs"), suggesting that the work is there-if the associate takes responsibility for finding it. Associates soon understand that it is the hours that count as well as the quality of work, and that logging long hours avoids calling attention to the possibility that an individual is, in fact, underutilized by his or her superiors. The risk is driven home by the stories of law firms that have fired-or facilitated the leave taking of-associates who are perceived as weak producers. ${ }^{34}$

A small number of large prominent law firms report that they do not have minimum hourly requirements, and those firms have garnered a reputation for being better places to work because of that practice. 35 But these firms continue to keep track of the hours logged by associates. The ongoing data collection appears to produce conditions somewhat similar to those at firms with minimum hours. A subset of associates report extremely large numbers of hours. The explanation is that the best associates are always in demand by partners. Similarly, associates whose hours are much lower are encouraged to

33. See Curtis, supra note 30 , at 68-69 (describing the project).

34. As one lawyer explained: "If they're not working, they're not getting any training .... A third year associate not doing anything does not become a fourth year associate as far as experience is concerned. And when they do get work, they tend to overbill." See Terry Carter, Taking up the Slack, A.B.A. J., Oct. 2001, at 22 (quoting a lawyer working at a Boston law firm, employing more than 500 people, and gaining press attention for laying off lawyers).

35. In interviews, lawyers at such firms report that the absence of required hours and the lockstep salaries increase firm morale and contribute to a team spirit within the firm. Avoidance of internecine warfare about salaries and bonuses is regarded as worth whatever problems are caused by perceived differences among associates and partners about the relative value of work done by individual lawyers. 
make themselves available for work; for some, low hours are regarded as an indication of less than stellar work or work habits and a reason for dismissal (phrased usually as "it doesn't look like things are working out for you here").

In short, in most law firms, associates come to realize that they are regarded and graded as profit centers: the more hours that they bill in ways chargeable to clients, the more they offset the generous salaries paid to them. If the system of required hours makes it likely that associates will cheat, it is equally likely that firms will not monitor the associates closely because the firms stand to benefit from the hours logged. Incentives for firms to be above reproach in financial dealings with clients are undermined by the increasing difficulty for law firms to remain solvent while continuing to meet (or to set) market rates in paying partners and associates.

Given that most major law firms rely on hours as a measure of value, both internal and external, what, if anything, might prompt alteration of that practice? We are not the first to ask this question. As noted, a movement exists for what is now termed "alternative billing" in which, at the prompting of some clients, firms are experimenting with various substitutes for hourly billing. ${ }^{36}$ However, as one analyst of the system has explained, hourly billing survives and pervades because of its simplicity, its potential reviewability, its familiarity, its administrability, its perceived safety, and perhaps most importantly from our perspective, because it provides a surrogate for value when value is hard to calculate.37 Further, as we discussed at the outset, contemporary legal doctrine anchors billing to hours for statutory fee-shifting cases and continues in other cases to use them as a touchstone. 38 Therefore, we concentrate on whether, within the practice of billing for time, changes could occur.

Two sources of change-the market and regulation-are, we believe, beginning to generate pressures. The picture we sketched above is spiraling sufficiently far out of control as to prompt law firms to revisit their own practices. As the number of hours becomes the primary concern, the quality and purposes of work recede. Inflationary pressures become so great that inefficiencies develop, producing the proverbial tipping point. Sophisticated

36. See supra note 7.

37. See Rees Morrison, Why Billable Hours Survive (2002) (unpublished manuscript, on file with authors).

38. A very small set of cases departs from the hourly model by setting fees ex ante through what is termed an "auction." While being very high profile, the actual number of such cases (as of this writing) is very small and their place in the fee award case law confined to discrete situations. See, e.g., In re Auction House Antitrust Litig., 197 F.R.D. 71 (S.D.N.Y. 2000); THIRD CIRCUIT TASK FORCE REPORT ON SELECTION OF CLASS COUNSEL, supra note 7; Jill E. Fisch, Aggregation, Auctions, and Other Developments in the Selection of Lead Counsel Under the PSLRA, 64 LAW \& CONTEMP. PROBS. 53 (2001). 
private clients and judges (as a form of "public client"39) are already in rebellion. Both have the clout to take steps to control costs, by restricting staffing, setting limits on research, and cutting bills for copying, faxing, and travel. 40

Moreover, we write as public outcries against professional privilege are raised in the context of the Enron bankruptcy, which has entered the lexicon as a shorthand for business corruption. Accountants are the center of the focus in terms of oversight, but the underlying challenge is about falsifying claims of value. While much of the current discussion of Enron focuses on lapses stemming from insufficient self-regulation by accountants, the question of the role of lawyers is not far behind. Another source of pressure may also come from abroad, as the insularity of the American bar will likely also be eroded through transnational business exchanges. Given the legal profession's long and successful protection of its own guild privilege, it may well want to develop additional forms of self-regulation to stave off third-party regulation.

Pressures for reform are also working from within. The burgeoning literature in both academia and the popular press document the intense dissatisfaction of new associates with the quality of life in large law firms;41 many senior lawyers also report the loss of joy in their work, and both young and old complain about the pressures to bill a required number of hours. ${ }^{42} \mathrm{As}$ unhappy lawyers evaluate the constraints on their lives and bemoan the loss of time to spend with people (young and old) outside their workplaces, they are also launching projects in bar associations, in law firms, and in law schools to question some of the contemporary practices. 43 We think a market exists for some law firms with nationwide reputations and influence to take steps toward revising their modes of billing and to make those innovations a selling point to

39. See Judith Resnik, Money Matters: Judicial Market Interventions Creating Subsidies and Awarding Fees and Costs in Individual and Aggregate Litigation, 148 U. PA. L. REV. 2119 (2000) (discussing the judiciary's role in generating marketplace norms).

40. See, e.g., Sulkowska v. New York, 170 F. Supp. 359 (S.D.N.Y. 2001) (disallowing claims for duplicative hours and for time expended on administrative tasks such as filing, photocopying, and faxing); Colbert v. Furomoto Realty, Inc., 144 F. Supp. 2d 251 (S.D.N.Y. 2001) (noting that time spent on clerical duties should be compensated, but at a lower clerical rate); see also Ross, supra note 10, at 100-03 (focusing on overstaffing), 117-21 (noting limits on research), 143-45 (reviewing copying, faxing, etc.), 148-51 (focusing on travel).

41. See, e.g., Boston Bar Association, Facing the Grail: Confronting the Cost of WorkFamily Imbalance, A REPORT FROM THE BOSTON BAR ASSOCIATION TASK FORCE ON Professional Challenges and Family Needs (1999); Patrick J. Schiltz, On Being a Happy, Healthy, and Ethical Member of an Unhappy, Unhealthy, and Unethical Legal Profession, 52 VAND. L. REV. 871 (1999).

42. See, e.g., M. Cathleen Kaveny, Billable Hours in Ordinary Time: A Theological Critique or the Instrumentalization of Time in Professional Life, 33 LOY. U. CHI. L.J. 173 (2001); see also Schiltz, supra note 41; Guberman, supra note 14.

43. See, e.g., Boston Bar Association, supra note 41 (describing how the pressures are especially acute for women, who often shoulder the major share of childcare and other care giving responsibilities). 
clients and for recruiting and retaining employees. Internal benefits may be reaped as well. Firms could benefit from competition among associates to do quality work rather than pile up hours. Given public distress and private angst in many segments of the legal profession about billing, the prospect of some form of change is not fanciful.

Assuming, then, the possibility of change, what might law firms and the academy teach about billing? Here, flights of fancy seem appropriate as a means of pressing against conventional wisdom, itself an artifact of a very recent set of changes in the structure of the bar and legal practice. Return to the questions that framed our earlier discussion of the problems that adhere in the goal of honest billing. What is "work" that ought to be billed? Who judges how much of that work is necessary? Take just one example, the disputed boundary between busy work and competent lawyering. Overstaffing is a common complaint by clients. Whether conferences are necessary, how much discovery is warranted, whether lawyers should be used for undemanding yet important tasks such as filing documents, whether the quantity and quality of document review are appropriate-all these are points of friction in which the lawyer's view of what is appropriate and necessary can be called into question.

Imagine that law firms put all those questions on the table and convened firm-wide discussions with associates and partners about the rules and practices that a particular firm would adopt about billing. By rules, we mean in-house decisions of what to bill-whether to bill full time for travel, how much to bill for recycled work product, what interval of time could be billed at all, and the like. Some of these items are already described-often at very general levels -in standard agreements between firms and their clients. Some are negotiated individually. We suggest a thorough rewriting of such rules, ideally with a range of clients brought into aspects of the conversation. In terms of practices, law firms would have to decide the literal processes of how billing actually ought to be done by lawyers.

Imagine, for example, a firm decision that no one could bill any client for less than ten minutes of time and that if amounts smaller than that were spent, no billable time would be logged. Imagine a rule that, as each lawyer departed for the day, that person had to leave a time sheet, and that no information logged later could be entered for that time period. Imagine that firms developed a system of team billing. The group of lawyers responsible for a given case might have projected caps on billing and no member of the group could enter hours without a more senior person agreeing that the time spent was necessary. Imagine a presumption against spending more than a certain number of hours a month, with a view that anyone logging over a specific amount had to meet with two senior members of the firm to explain the reality and propriety of excess hours. (Instead of minimum billable hours, imagine law practice with the conceit of maximum billable hours.) The practices of billing could shift from an individualistic activity to a cooperative event, with lawyers working on the same matter deciding together at the end of the day or 
week how many hours to bill. Further, junior lawyers could be told that they lack the authority to determine the amount of time to record, and rather that the responsibility for allocating work and counting hours rested with the partners in charge. Such changes would require firms to work hard to allocate jobs among lawyers, but the benefit would be that the lawyers could concentrate on the substantive projects without worrying about whether the hours spent added sufficiently to their monthly total.

Imagine a few other rules - that every new member of a law firm took a two day-long program in the firm's attitudes towards the profession, its clients, and itself, with billing as a part of that program. Assume as part of that curriculum, that all lawyers (new and old) attended sessions on the law of billing, in which lawyers had to read decisions in which judges decide how much to pay particular lawyers. Although under the current shape of the law, the lawyers most supervised through that system are those taking statutory-fee shifting cases paid by losing defendants, lawyers in law firms would be asked to use the case law for guidance about their own judgments on billing. The judicial analyses of bills extends to questions about which tasks are necessary, overstaffing, reconciliation of hours among many lawyers, and other indicia of the worth to clients of efforts by lawyers on their behalf. 44 In addition, state and federal lawyer grievance committees have opinions about various billing practices, as do the American Bar Association and state bar associations. Law firms might use those materials as a springboard for interrogation of their own customs.

Turn then to a law school course on the idea of the relationships among value, compensation, and time. Just as Deborah Rhode has argued for the pervasive method of teaching about ethics, 45 this facet of ethics has salience to many aspects of legal education. How lawyers are paid is a topic that might be located in several parts of the curriculum, beginning with the first year Procedure course, running through offerings in Law and Economics, Professional Responsibility, Jurisprudence, and clinical programs. 46 One focus

44. See, e.g., Okot ex rel. Carlo v. Conicelli, 180 F. Supp. 2d 238 (D. Me. 2002) (reducing the amount of hours spent searching for an expert and cutting charges for photocopying in half); Rodriguez v. McLoughlin, 84 F. Supp. 2d 417 (S.D.N.Y. 1999) (rejecting a request for reimbursement from attomeys who spent a very small amount of time working on a case); Quinn v. Nassua County Police Dept., 75 F. Supp. 2d 74 (E.D.N.Y. 1999) (reducing billable hours based on a ruling that a junior attorney had served primarily as observer at a trial).

45. See generally Deborah RHOde, Professional RESPONSIBILITY: ETHICS BY THE PERVASIVE METHOD (2d ed. 1998).

46. The growth of clinical education has given law students an understanding of attorney-client relationships and of how law is made through such exchanges. But the costs of such work are not, to our knowledge, revealed by clinical programs. We do not here suggest that clinics start billing for services but, rather, that clinical programs are one of several places in which students might be taught about the relationship between time spent and help received. Cf. Andrea Christensen Luby, Shadow Markets for Legal Services: 
would be external: on the rise in the 1960 s of the billable hours, the market pressures for them, the segments of the profession (such as criminal defense lawyers) who labor under fee caps, those who work for fixed salaries, and those who rely on negotiations to set prices, the complexity of assessing value conferred, the other trades and professions that do bill by the hour (such as car mechanics, plumbers, and psychiatrists) or those that do not (such as writers and politicians). Another set of issues would be on the effect of billing on the structure of law firms and the relationship with clients. Here, issues include whether billing practices ought to vary with the identity of the client (in terms of personal relationships and in terms of wherewithal to pay), how face-to-face relationships are either developed because of hourly billing (prompting more client oversight) or diminished, and whether distancing junior workers from clients facilitates problematic billing practices.

Another focus for law schools that take up the question of time should be internal, because law schools also deal in time and use it as a proxy for value. Classes are generally listed by the number of hours they meet, which in turn are translated into credits toward graduation. Recall that like the billable hour, this system is of relatively recent vintage, replacing a regime in which education came through clerking for senior lawyers and without fixed time parameters. The remunerative practice of law enables law schools to charge tuition and to raise endowments; hence law schools are implicated in and thrive upon the same culture of excess. Moreover, while some law schools have very specific practices in terms of regulating hours spent by professors and students to yield credits for graduation, others permit a lax market in credits in which individual professors are permitted to negotiate with individual students to provide credit for special seminars and research projects. Yet law schools do not totally rely on time as a measure of value. Credit hours are required but so are grades, in which judgments about quality are routinely proffered.

In sum, the topic of time and value is not one only about the "real world"-out there, after law school-but is about practices within law schools, which are also part of the real world of law. Teaching billing, valuable in itself, would also press law schools to acknowledge both the links to and the resemblances between the legal academy and the practice of law as well as to reflect on divergent metrics of value. We know that many of our suggestions are counter-cultural, yet we offer them to underscore the degree to which the very culture so easily bemoaned by legal academic, judge, and practicing lawyer alike is itself an artifact of a series of inter-related choices made and prices imposed on the education provided to lawyers-both in law school and after graduation. Those (like us) who have the freedom not to bill by the hour have an obligation to share in exploring the role of the billable hour in the law.

Beyond the Community-Based Approach, 17 YALE L. \& POL'Y REv. 563 (1998) (proposing that legal service clients pay for services). 
